\title{
FUNDING PATTERNS OF BIBLIOMETRICS RESEARCH
}

\section{MODELI FINANCIRANJA BIBLIOMETRIJSKIH ISTRAŽIVANJA}

\author{
Peter Kokol \\ Faculty of Electrical Engineering and Computer Science, University of Maribor, Maribor, Slovenia \\ Fakultet elektrotehnike računarstva, Sveučilište u Mariboru, Maribor, Slovenija
}

Abstract

To identify research funding patterns behind bibliometrics as a rapidly expanding science was the aim of the study presented in this paper. We analysed funding information of 8,622 bibliometric papers harvested from Web of Science, among which 1,786 (20.7\%) were Papers with Reported Funding (PRFs). The trend in number of PRFs funding in last five years was positive. The most productive countries in PRFs' production were China, the USA and the UK. The same countries were also the most prolific regarding how many times they were mentioned in funding acknowledgements. The number of PRFs published per country was related with OECD reported Gross Domestic Spending on R\&D for 2015. There was a significant correlation between number of PRFs per country and the number of all bibliometric papers per country. Far the most prolific funding agency was National Natural Science Foundation of China, followed by the European Commission and the USAs National Science Foundation. The Research trend and direction prediction is the most prolific research theme regarding the percent of PRF and thus most likely to get funded.

\section{INTRODUCTION}

Bibliometrics is a rapidly expanding science with increased translation to practice in different application areas $/ \mathbf{1} /, / \mathbf{2} /$. The identification of research funding patterns behind the expansion, was the aim of the study presented in this paper. The results of such studies might in-

\section{Sažetak}

Cilj istraživanja predstavljenog $\mathrm{u}$ ovom radu bio je identificirati obrasce financiranja istraživanja iz područja bibliometrije kao znanosti koja se brzo širi. Analizirane su informacije o financiranju 8.622 bibliometrijskih radova prikupljenih iz Web of Science, od kojih je 1.786 (20,7\%) bilo radova s prijavljenim financiranjem (PRF). Trend $\mathrm{u}$ broju PRF-ova u posljednjih pet godina bio je pozitivan. Najproduktivnije zemlje u proizvodnji PRF-a bile su Kina, SAD i Velika Britanija. Iste su zemlje bile i najplodnije u pogledu koliko su puta spomenute u priznanjima za financiranje. Broj PRF-ova objavljenih po zemlji povezan je s OECD-ovim izvješćem o bruto domaćoj potrošnji na istraživanje i razvoj za 2015. Postoji značajna korelacija između broja PRF-ova po zemlji i broja svih bibliometrijskih radova po zemlji. Daleko najplodnija agencija za financiranje bila je Nacionalna zaklada za prirodne znanosti u Kini, a slijede je Europska komisija i Nacionalna zaklada za znanost SAD-a. Predviđanje trenda i smjera istraživanja je najplodnija tema istraživanja u odnosu na postotak PRF-a i stoga najvjerojatnije da će se financirati.

form an interested researcher about possible sources of funding, since there are too many funding agencies to be aware of all of them. Additionally it may point him to successful institutions which could be sought for possible partnerships, and help him to identify research themes and application areas most likely to be 
funded. While it is hard to get data about funding from funding bodies, especially about specific research fields like bibliometrics, we followed Wang and Shapira /3/ proposal that funding acknowledgements found in bibliographical databases could be analysed to extract funding patterns. However, Rigby /4/ and Tang, Hu and Liu /5/, warned that, due to discrepancies in funding acknowledgements, the uncritical use of funding information may lead to bias in interpreting the results of such analyses. Due to their accuracy /6/ we used funding information provided in Web of Science (WoS, Clarivate Analytics, USA) database in the analyses performed in our study.

\section{METHODS}

The bibliometric research papers were harvested on $5^{\text {th }}$ of February, 2018, from the WoS - All databases collection using advanced search. The search strings $T S=$ (bibliometric $\left.^{*}\right)$ and PY $=(2012-2017)$ and $F O=\left(a^{*}\right.$ or $b^{*}$ or $c^{*}$ or $d^{*}$ or $e^{*}$ or $f^{*}$ or $g^{*}$ or $h^{*}$ or $i^{*}$ or $j^{*}$ or $k^{*}$ or $l^{*}$ or $m^{*}$ or $n^{*}$ or $o^{*}$ or $p^{*}$ or $q^{*}$ or $r^{*}$ or $s^{*}$ or $t^{*}$ or $u^{*}$ or $v^{*}$ or

$z^{*}$ or $x^{*}$ or $y^{*}$ or $w^{*}$ or $1^{*}$ or $2^{*}$ or $3^{*}$ or $4^{*}$ or $5^{*}$ or $6^{*}$ or $7^{*}$ or $8^{*}$ or $9^{*}$ or $0^{*}$ ) was used for identifying funded papers, and the string $T S=$ (bibliometric $\left.{ }^{*}\right)$ and PY $=(2012-2017)$ for all bibliometric papers. The country, institution and funding agencies names in WoS are stored without strict standards /7/. Thus, we analysed extracted names manually, and merged variations into one entity, for example People R China and China into China; England, the United Kingdom and UK into UK: USA, the United States, and the United States of America into USA; Brazil and Brasil into Brazil; University of Harvard and Univ Harvard into University of Harvard; EU, EC, European Commission and European Union into EC, and similar. All country names were analysed. However, due to the fact that there were 7,477 different institution names (5,576 with occurrence less than 3) and 1,931 funding agencies names (1,810 with occurrence less than 3), we analysed and merged only the names for 10 productive institutions and 20 most prolific funding agencies. The analysis process is shown in Figure 1.

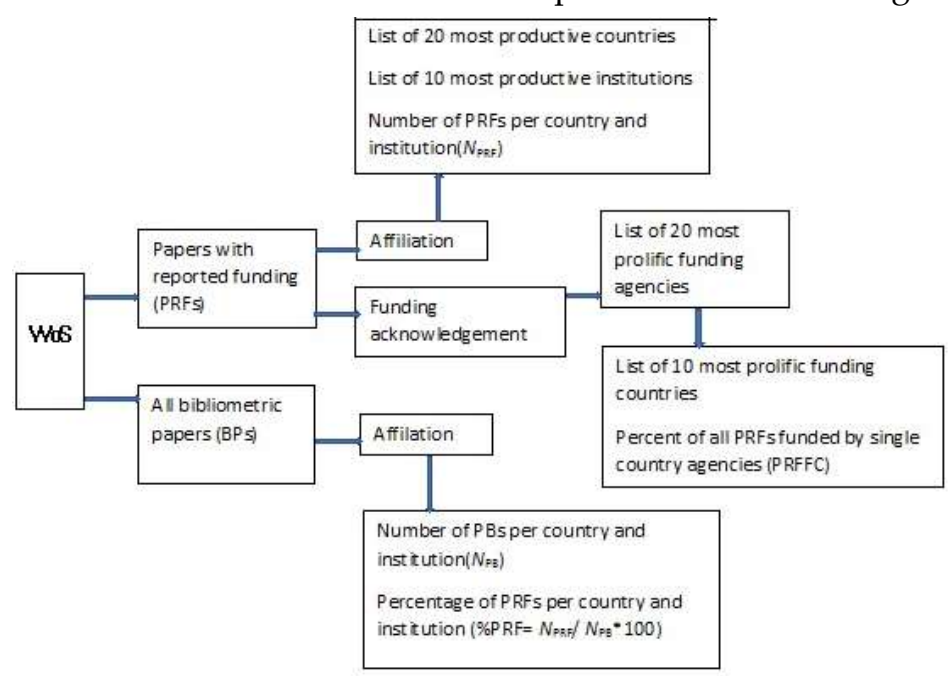

Figure 1. The block diagram of the analysis process

Additionally, abstracts and titles of funded papers were analysed using the VOSViewer software. General and common terms were excluded from the analysis. A cluster map was generated using terms with occurrence larger than 30. The cluster map was analysed using thematic analysis to identify the funded research themes and application area. For each theme we calculated its respective \%PRF.

\section{RESULTS AND DISCUSSION}

The search resulted in 8,622 papers, among them 1,786 (20.7\%) PRFs. This is, for example, less than in Robotics, where there were $31 \%$ of PRFs /7/, and more than in Nursing 
Informatics, where there were $15 \%$ of PRFs $/ 8 /$. The trend in production of BPs, PRFs and percentage of PRFs is positive (Figure 2). Compared to the trend in overall production of research papers the trend in production od BPs was steeper. The trend in the production of PRFs was smaller than both the trend in production of all papers and the trend in production of BPs.

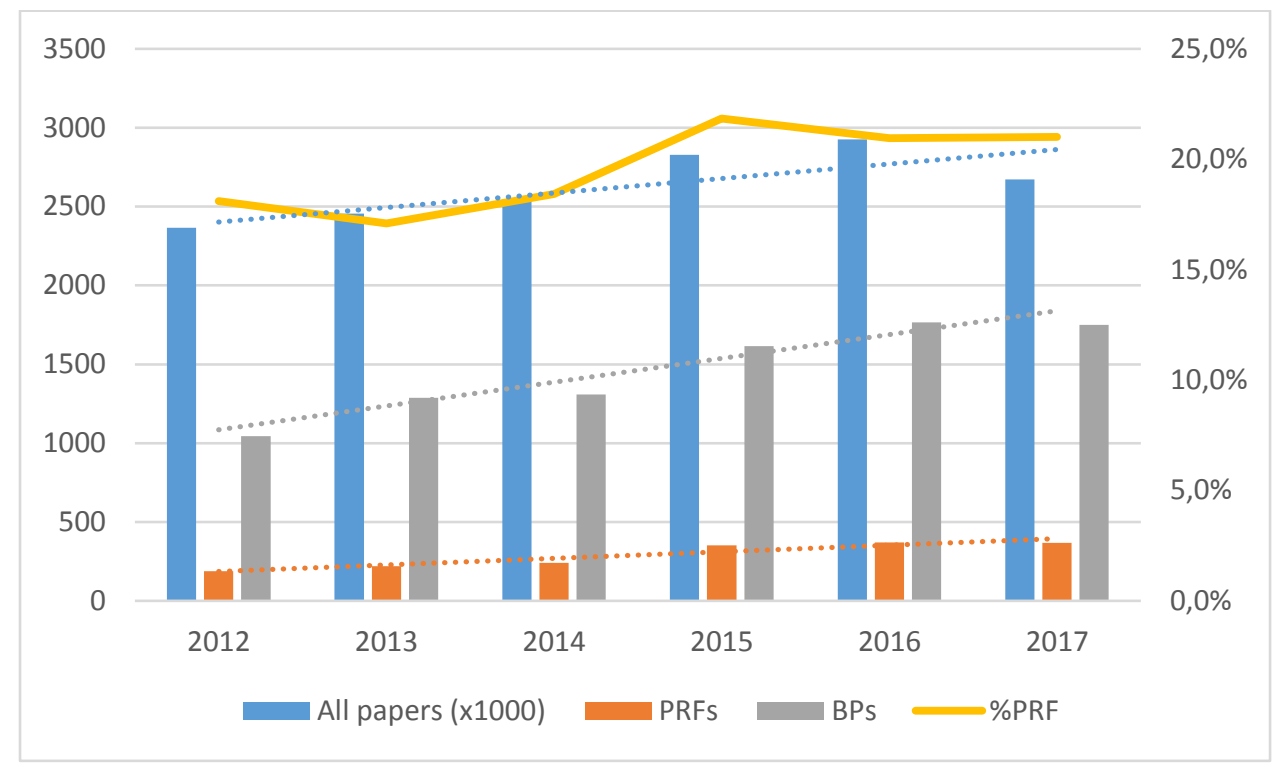

Figure 2. The trends in production of published papers and funding

Far the most prolific funding agency was National Natural Science Foundation of China, followed by the European Commission and the USAs National Science Foundation (Table 1). On the country level, China was the most prolific funding country (PRFFC $=38.9 \%$ ), followed by the USA (PRFFC $=10.3 \%$ ), Brazil and Spain $(\mathrm{PRFFC}=6.3 \%)$, the EC (PRFFC $=5.8 \%)$, Canada $(\mathrm{PRFFC}=4.1 \%)$, the UK (PRFFC $=3.4 \%)$. Japan $(\mathrm{PRFFC}=3.0 \%)$, South Korea $(\mathrm{PRFFC}=2.4 \%)$ and
Russia (PRFFC $=1.7 \%$ ). These country ranks are, with some exceptions, congruent with the OECD reported Gross Domestic Spending on R\&D for 2015 /9/, where the USA is ranked $1^{\text {st }}$, China $2^{\text {nd }}$, Brazil 10 $10^{\text {th }}$, Spain $15^{\text {th }}$, EC $3^{\text {rd }}$, Canada $13^{\text {th }}$, the UK $8^{\text {th }}$, Japan $4^{\text {th }}$, South Korea $6^{\text {th }}$ and Russia $9^{\text {th }}$.The differences in ranking could show that countries like Canada, Brazil and Spain are investing more in bibliometric research, than in research in general.

Table 1. The 20 most prolific funding agencies

FUNDING AGENCY

NATIONAL NATURAL SCIENCE FOUNDATION OF CHINA 205

EUROPEAN COMMISION

NATIONAL SCIENCE FOUNDATION (USA)

CNPQ (BRASIL)

FUNDAMENTAL RESEARCH FUNDS FOR THE CENTRAL UNIVERSITIES (CHINA) 30

NATIONAL INSTITUTES OF HEALTH (USA) 29

$\begin{array}{lr}\text { NATIONAL SOCIAL SCIENCE FOUNDATION OF CHINA } & 20\end{array}$

$\begin{array}{lr}\text { CAPES (BRASIL) } & 20\end{array}$

$\begin{array}{lr}\text { RUSSIAN GOVERNMENT } & 19\end{array}$ 


\begin{tabular}{lr}
\hline \hline CHINA SCHOLARSHIP COUNCIL & 17 \\
CANADIAN INSTITUTES OF HEALTH RESEARCH & 11 \\
KOREAN GOVERNMENT & 11 \\
CHINA POSTDOCTORAL SCIENCE FOUNDATION & 10 \\
SWEDISH RESEARCH COUNCIL & 10
\end{tabular}

MINISTRY OF EDUCATION SCIENCE AND TECHNOLOGICAL DEVELOPMENT OF THE REPUBLIC OF SERBIA

SAO PAULO RESEARCH FOUNDATION FAPESP (Brazil)

The production of PRFs was distributed between 86 countries. The most productive countries were China, followed by the USA and the UK, producing more hen three quarters of RFPs. The overall production of bibliometrics papers was spread between 142 countries The most productive countries were USA, followed by China and the UK, producing cca. two fifths of BPs.

China was the most prolific country regarding $\% \mathrm{PRF}_{\mathrm{c}}$, followed by South Korea and Poland. Brazil and India, were the countries with the least $\% \mathrm{PRF}_{\mathrm{c}}$. This is surprising, given the high rank of Brazil in the list of most prolific funding countries. Despite the large difference between maximal $(50.5 \%)$ and minimal $(10.6 \%)$ ${ }_{\mathrm{PRF}}$, the partial correlation test with the number of researchers per 1,000 inhabitants as a control variable showed a significant correlation between $N_{\text {PRF }}$ and $N_{B P}$ (R2 $=0.88$,

Table 2. The 20 most productive countries $\mathrm{p}=0.00$ ) That means that in general production of PRFs and BPs per country are proportionate. Most of the countries from Table 2 are also among 20 most productive countries regarding SciMago country rank. The only exceptions are Belgium and Malaysia, ranked $21^{\text {st }}$ and $34^{\text {th }}$ in the SciMago ranking. Two countries exceeding their ranks in SciMago are Spain and Brazil, ranking fourth (SciMago rank $=10$ ) and sixth (SciMago rank=15) respectively. That shows that the above four countries probably invest more in bibliometrics' research than in research in general. The Spearman test showed significant correlation between the country ranks regarding production of PRFs and SciMago Country ranks, meaning that, on average investment in bibliometrics are congruent with countries investments in science in general.

\begin{tabular}{lllll} 
& & & \multicolumn{2}{l}{ SciMago } \\
COUNTRY & N & NRF & NвPFF & country rank \\
CHINA & & & \\
THE USA & & 1282 & $50,5 \%$ & 2 \\
THE UK $^{*}$ & 405 & 1433 & $28,3 \%$ & 1 \\
SPAIN $^{*}$ & 237 & 873 & $27,1 \%$ & 3 \\
CANADA $^{*}$ & 148 & 699 & $21,2 \%$ & 10 \\
BRAZIL $^{*}$ & 131 & 353 & $37,1 \%$ & 7 \\
AUSTRALIA & 78 & 733 & $10,6 \%$ & 15 \\
THE NETHERLANDS & 72 & 280 & $25,7 \%$ & 14
\end{tabular}




\begin{tabular}{lllll}
\hline \hline GERMANY* & 65 & 431 & $15,1 \%$ & 4 \\
SOUTH KOREA & 61 & 140 & $43,6 \%$ & 12 \\
ITALY* & 60 & 340 & $17,6 \%$ & 12 \\
SWEDEN & 44 & 124 & $35,5 \%$ & 18 \\
FRANCE & 42 & 192 & $21,9 \%$ & 6 \\
TAIWAN & 38 & 200 & $19,0 \%$ & 17 \\
JAPAN* & 36 & 121 & $29,8 \%$ & 5 \\
RUSSIA & 32 & 109 & $29,4 \%$ & 13 \\
BELGIUM & 29 & 112 & $25,9 \%$ & 21 \\
MALAYSIA & 29 & 73 & $39,7 \%$ & 34 \\
INDIA & 28 & 237 & $11,8 \%$ & 9 \\
POLAND & 26 & 64 & $40,6 \%$ & 19
\end{tabular}

${ }^{*} \mathrm{G} 20$ countries

The most productive institutions (Table 3) are Chinese Academy of Sciences, Consejo Superior de Ivestigaciones Cientificas and Univeristy of Wuhan. Majority of the 10 most productive institutions are located in China and USA. Chinese institutions are also the most prolific regarding the $\% \mathrm{PRF}_{i}$, which for most Chinese institutions is larger than $70 \%$. The largest $\% \mathrm{PRF}_{\mathrm{i}}$ by a non Chinese institution was achieved by Georgia institute of technology $\left(\% \mathrm{PRF}_{\mathrm{i}}=56.0 \%\right)$.

Table 3. The 10 most productive institutions in bibliometric literature production

$\begin{array}{llll}\text { INSTITUTION } & \text { NPRF } & N_{\mathrm{BP}} & \% \mathrm{PRF}^{\mathrm{i}} \\ \text { CHINESE ACADEMY OF SCIENCES } & 137 & 182 & 75,3 \% \\ \text { CONSEJO SUPERIOR DE INVESTIGACIONES CIENTIFICAS (Brazil) } & 91 & 244 & 37,3 \% \\ \text { WUHAN UNIVERSITY (China) } & 88 & 119 & 73,9 \% \\ \text { UNIVERSITY OF GRANADA (Spain) } & 77 & 188 & 41,0 \% \\ \text { INDIANA UNIVERSITY SYSTEM (USA) } & 70 & 180 & 38,9 \% \\ \text { GEORGIA INSTITUTE OF TECHNOLOGY (USA) } & 65 & 116 & 56,0 \% \\ \text { UNIVERSITY OF MICHIGAN SYSTEM (USA) } & 54 & 152 & 35,5 \% \\ \text { UNIVERSITY OF MONTREAL (Canada) } & 54 & 130 & 41,5 \% \\ \text { PEKING UNIVERSITY (China) } & 53 & 116 & 45,7 \% \\ \text { BEIJING INSTITUTE OF TECHNOLOGY } & 48 & 68 & 70,6 \%\end{array}$

The thematic analysis of the clusters and terms in Figure 3, revealed five research themes and 10 application areas emerging in funded research, namely:
- Research evaluation, performance and funding (yellow colour); $\% \mathrm{PRF}=27 \%$,

- Information sciences and digital humanity (violet colour); $\mathrm{PRF}=18 \%$, 
- Analysis of publications and patents trends in nanotechnology and health (blue colour); $\mathrm{PRF}=29 \%$,

- Research trends and directions prediction in environmental sciences, chemistry, psychiatry and law, (green colour); $P R F=32 \%$,
- Bibliometric, content and network analysis in sustainability and management areas (red colour); $\mathrm{PRF}=28 \%$.

The Research trend and direction prediction is the most prolific research theme regarding $\% \mathrm{PRF}$ and thus most likely to get funded.

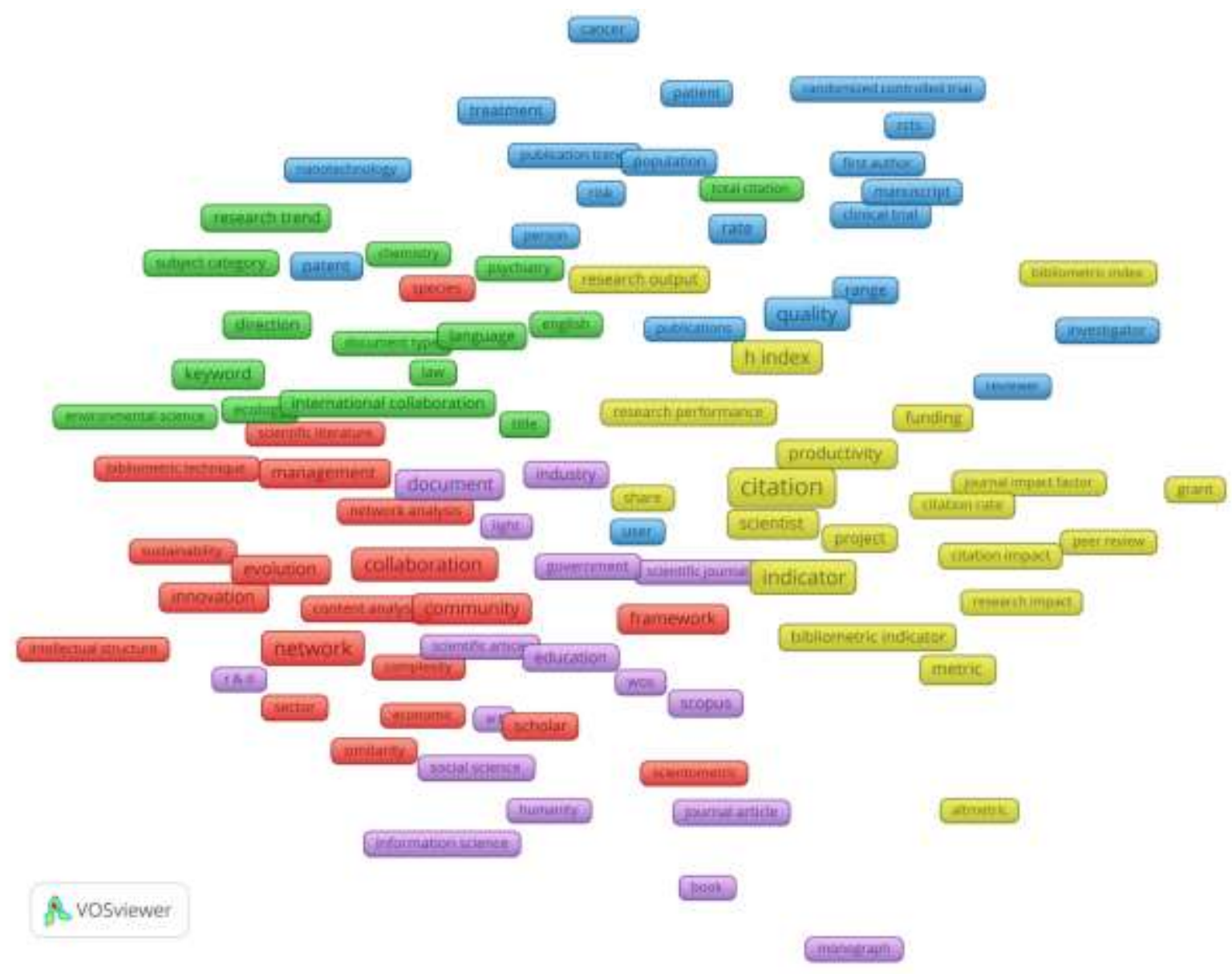

Figure 3. PRFs research themes and application areas

\section{CONCLUSION}

The trend in production of research papers in general, BPs, PRFs and percentage of PRFs was positive. However the trend in BPs production was steeper than overall production of research papers and also steeper than the production of PRFs. The most productive and prolific countries like China, the USA and the UK are also among the most productive regarding all scientific output. They are also most economically develop, being among G20 countries and have largest Gross Domestic Spendings on R\&D. Far the most prolific funding agency was National Natural Science
Foundation of China, followed by the European Commission and the USAs National Science Foundation. The most productive institutions are Chinese Academy of Sciences, Consejo Superior de Ivestigaciones Cientificas and the Univeristy of Wuhan. The Research trend and direction prediction is most likely to get funded.

Notes

/1/ C. B. Rock, A. V. Prabhu, C. D. Fuller, C. R. Thomas, and E. B. Holliday, "Evaluation of the Relative Citation Ratio, a New National Institutes of Health-Supported Bibliometric Measure 
of Research Productivity, among Academic Radiation Oncologists," J. Am. Coll. Radiol., vol. 15, no. 3, pp. 469-474, 2018.

/2/ U. Sandström and P. Van den Besselaar, "Funding, evaluation, and the performance of national research systems," J. Informetr., vol. 12, no. 1, pp. 365-384, 2018.

/3/ J. Wang and P. Shapira, "Funding acknowledgement analysis: an enhanced tool to investigate research sponsorship impacts: the case of nanotechnology," Scientometrics, vol. 87, no. 3, pp. 563-586, Jun. 2011.

/4/ J. Rigby, "Systematic grant and funding body acknowledgement data for publications: new dimensions and new contraversies for research policy and evaluation," Res. Eval., vol. 20, no. 5, p. 365, 2011.

/5/ L. Tang, G. Hu, and W. Liu, "Funding acknowledgment analysis: Queries and caveats," J. Assoc. Inf. Sci. Technol., vol. 68, no. 3, pp. 790-794, Mar. 2017.
/6/ P. Kokol and H. Blažun Vošner, "Discrepancies among Scopus, Web of Science, and PubMed coverage of funding information in medical journal articles," J. Med. Libr. Assoc. JMLA, vol. 106, no. 1, pp. 81-86, Jan. 2018.

/7/ C. Mejia and Y. Kajikawa, "Using acknowledgement data to characterize funding organizations by the types of research sponsored: the case of robotics research," Scientometrics, vol. 114, no. 3, pp. 883-904, Mar. 2018.

/8/ P. Kokol and H. Blažun Vošner, "Nursing informatics research: A bibliometric analysis of funding patterns," Online J. Nurs. Inform., vol. 21, no. 2, 2017.

19/ "Research and development (R\&D) - Gross domestic spending on R\&D - OECD Data," theOECD. [Online]. Available: http://data.oecd.org/rd/gross-domesticspending-on-r-d.htm. [Accessed: 14-Mar-2018]. 